\title{
Ultrasound-Based Neuronavigation and Spinal Cord Tumour Surgery - Marriage of Convenience or Notified Incompatibility?
}

\author{
Ultrason Tabanlı Nöronavigasyon ve Omurilik Tümörü Cerrabisi - Bir \\ Kolaylık mi yoksa Uyumsuzluk mu?
}

Todor SHAMOV ${ }^{1}$, Tihomir EFTIMOV ${ }^{1}$, Ara KAPRELYAN² ${ }^{2}$ Yavor ENCHEV ${ }^{3}$

${ }^{1}$ Military Medical Academy, Department of Neurosurgery, Sofia, Bulgaria

${ }^{2}$ Medical University, Department of Neurology, Varna, Bulgaria

${ }^{3}$ Medical University, Department of Neurosurgery, Varna, Bulgaria

Corresponding Author: Yavor ENCHEV / E-mail: dr.y.enchev@gmail.com

\begin{abstract}
AIM: The study aimed to examine the position of three-dimensional (3D) neurosonography and the advantages and disadvantages of ultrasound-based neuronavigation in spinal cord tumour surgery.

MATERIAL and METHODS: During the period July, 2007- February 2011, 28 patients with spinal cord tumours were operated in our neurosurgical clinic. All patients underwent intraoperative 3D neurosonography by means of SonoWandTM and SonoWand InviteTM ultrasound-based neuronavigation systems.

RESULTS: Intraoperative 3D neurosonography was used for 6 intramedullary tumours (5 ependymomas and 1 astrocytoma) and 22 extramedullary tumours (8 neurinomas, 10 meningiomas and 4 filum terminale ependymomas). During the performed spinal tumour surgery, snapshots of the 3D images of the surgical situation were obtained. Post-operative results, based on the control MRI findings and the patients' score on Karnofsky Performance Scale, were evaluated during the third month after the surgery.

CONCLUSION: Ultrasound-based neuronavigation is a promising tool in extramedullary tumour surgery, especially of meningiomas and neurinomas, ensuring better control on the extent of tumour excision. In patients with intramedullary tumours, however, the use of 3D neurosonography for more precise control on the extent of radical tumour excision is not possible. In general, ultrasound-based neuronavigation has not added much to the surgical management of spinal cord tumors.
\end{abstract}

KEYWORDS: Spinal cord surgery, Spinal cord tumours, Intraoperative three-dimensional (3D) neurosonography, SonoWand ultrasound-based neuronavigation system

\section{öz}

AMAÇ: Bu çalışma, omurilik tümörü cerrahisinde üç boyutlu (3D) nörosonografinin konumunu ve ultrason tabanlı nöronavigasyon avantajlarını ve dezavantajlarını incelemeyi amaçlamıştır.

YÖNTEM ve GEREÇLER: Temmuz 2007- Şubat 2011 döneminde omurilik tümörlü 28 hasta nöroşirürji kliniğimizde ameliyat edildi. Tüm hastalarda SonoWandTM ve SonoWand InviteTM ultrason tabanlı nöronavigasyon sistemleriyle intraoperatif 3D nörosonografi yapıldı.

BULGULAR: Intraoperatif 3D nörosonografi 6 intramedüller tümör (5 epandimom ve 1 astrositom) ve 22 ekstramedüller tümörde (8 nörinom, 10 menenjiyom ve 4 filum terminale ependimomu) kullanıldı. Omurilik tümörü cerrahisi yapılırken cerrahi durumun 3D görüntülerinin çekimleri yapıldı. Postoperatif sonuçlar, kontrol MRG bulguları ve hastaların Karnofsky Performans Ölçeğindeki skoru temelinde postoperatif sonuçlar cerrahiden üç ay sonra değerlendirildi.

SONUÇ:Ultrason tabanlı nöronavigasyon özellikle menenjiyomlar ve nörinomlar olmak üzere ekstramedüller tümör cerrahisinde ümit vadeden bir araçtır ve tümör eksizyonu miktarının daha iyi kontrolünü mümkün kılar. Ancak intramedüller tümörlü hastalarda 3D ultrasonografinin radikal tümör eksizyonunun daha iyi kontrol edilmesi için kullanılması mümkün değildir. Genel olarak ultrason tabanlı nöronavigasyon omurilik tümörlerinin cerrahi tedavisine fazla katkıda bulunmamıştır.

ANAHTAR SÖZCÜKLER: Omurilik cerrahisi, Omurilik tümörleri, İntraoperatif üç boyutlu (3D) nörosonografi, SonoWand ultrason tabanlı nöronavigasyon sistemi 


\section{INTRODUCTION}

Spinal cord tumours account for approximately $10 \%$ of the central nervous system (CNS) tumours, and one third of them represent primary tumours of the spinal cord. Surgical treatment of spinal cord tumours has been commenced in the beginning of the twentieth century (22). In 1978, Reid was the first to apply the intraoperative ultrasound imaging in spinal cord tumour surgery (21). In the course of time, the position of neurosonography has strengthened in spinal cord surgery $(11,16,20)$. However, at that time major disadvantages of the applied ultrasound techniques were the two-dimensional representation of images and the impossibility for positioning the surgical instruments within the surgical site.

The introduction of frameless stereotactic surgery in 1980 s and its inevitable widespread application in cranial neurosurgery $(3-10,18,23)$ was naturally followed by the development of systems for spinal procedures as initially for positioning of transpedicular screws in spinal stabilization cases $(11,17)$. In 2005 and 2006, the first reports on the application of ultrasound-based neuronavigation systems in spinal cord surgery were published $(1,14)$. The introduction of the $12 \mathrm{MHz}$ linear transducer, with its high resolution and image quality, by Unsgard et al. has found its application in microneurosurgery, compatible with the use of ultrasoundbased neuronavigation systems $(24,25)$.

Some of the structures situated in the spinal cord are fixed, while others are moving, due to certain physiological factors. Hence, the contents of the terms "intraoperative 3D sonography" and "neuronavigation procedure" need to be clarified.

Intraoperative 3D sonography produces a snapshot of the structures in the spinal cord, obtained after fast ultrasound registration with a calibrated transducer (a reference star). By this method, it is possible to achieve B-scan images in different planes. In case of intra-medullary tumours and some small (by volume) extra-medullary tumours, the target tumour mass is mobile (due to the physiological mobility of the spinal cord) and it is impossible to make a volumetric 3D reconstruction of the tumour which can be used in neuronavigation. However, the performance of repeated registration and the acquisition of a series of new images at a certain stage of the surgical intervention are feasible.

During the neuronavigation procedure, the registered structures in the spinal canal are relatively immobile. After the performance of registration with a calibrated transducer, a real time image can be acquired through a calibrated probe or another instrument, reflecting the position of the tip of the calibrated instrument onto the respective registered target.

The aim of this study was to examine the role of threedimensional (3D) neurosonography and the advantages and disadvantages of ultrasound-based neuronavigation systems in spinal cord tumour surgery.

\section{MATERIAL and METHODS}

From the second half of 2007 until the beginning of February 2011, 28 patients with spinal cord tumours were operated at the Clinic of Neurosurgery, Military Medical Academy Sofia. All patients were preoperatively diagnosed by MRI and examined ultrasonographically by the SonoWand system intraoperatively. The mean age of the patients was $51(+/-19)$ years and the male to female ratio was 13 to 15 .

The only inclusion criterion for the patients in this prospective study was the intradural (both intra-medullary and extramedullary) localization of the tumour. The surgical results, based on post-operative MRI, as well as the quality of life by means of the patient's score on Karnofsky Performance Scale, were evaluated during the third month after the neurosurgical procedure.

Since the second half of 2007, the Clinic of Neurosurgery has been equipped with the SonoWand ${ }^{\mathrm{TM}}$ ultrasound-based neuronavigation system (SonoWand; Mison, Trondheim, Norway). Since the beginning of 2009, the SonoWand Invite ${ }^{\mathrm{TM}}$ neuronavigation system, working with a linear $12 \mathrm{MHz}$ transducer, was additionally put into use. These neuronavigation systems were applied in three different ways, namely, as an ultrasound imaging system, a conventional neuronavigation system and an integrated ultrasound-based neuronavigation system, utilizing the advantages of both technologies.

Both systems are based on optical encoding technology, enabling calibration of the ultrasound probe and threedimensional reconstruction of the images, obtained during the intraoperative ultrasound examination, as well as feasible real time navigation (Figure $1 \mathrm{~A}, \mathrm{~B}$ ).

Keeping in mind that $8 \mathrm{MHz}$ and $10 \mathrm{MHz}$ transducers are used by the SonoWand navigation system, and a $10 \mathrm{MHz}$ transducer and $12 \mathrm{MHz}$ linear transducer by the SONOWAND INVITE ${ }^{\mathrm{TM}}$ navigation system, various types of transducers were used. In most of the cases, $10 \mathrm{MHz}$ and $12 \mathrm{MHz}$ transducers were used, with an optimal resolution at a depth range of 0.5 $-4 \mathrm{~cm}$, thus enabling the visualization of the structures in the spinal canal.

For tumours in the thoracic and lumbar spine, a standard frame, attached to the operating table was used to fix the reference star, and for lesions in the cervical spine, the reference star was attached to a three-point head rest.

Following the laminectomy or haemilaminectomy, thorough hemostasis was performed. For thoracic and lumbar spine tumours, the reference star was adjusted in a position over the surgical site. The surgical cavity was filled with sterile saline and registration of the pathological entity was carried out by tilting or translating and slipping of the ultrasound probe over the region of surgical interest. The process of registration took approximately 10-15 seconds. In order to avoid any artifacts due to respiratory intraoperative spinal movements, a 15-second expiratory state of the patient was maintained by the anesthesiologist. 

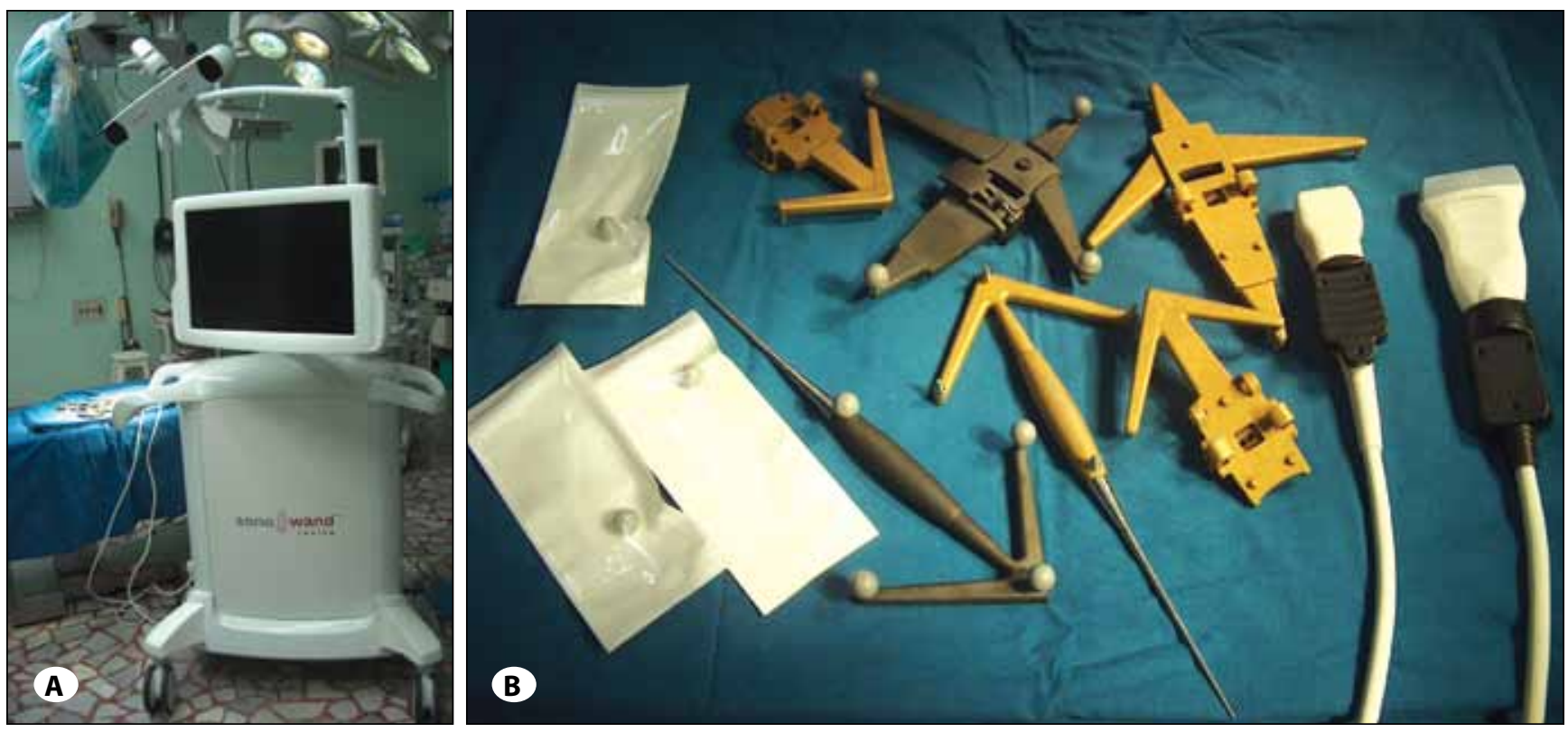

Figure 1: (A) Ultrasound based neuronavigation system SonoWand Invite ${ }^{\mathrm{TM}}$ (Mison, Trondheim, Norway). (B) Ultrasound transducers 10 and $12 \mathrm{Mhz}$ together with reference stars and calibrated referent probes compatible with neuronavigation system SonoWand Invite ${ }^{\mathrm{TM}}$.

A series of 100 to $2002 \mathrm{D}$ ultrasound images were produced by the applied system, which via software reconstruction were processed into a 3D reconstructed image. The process of software reconstruction took approximately 1 minute, thus enabling the performance of a new series of fast, repeated registrations, for example, after partial removal of the tumour or a shift of the target within the surgical site. After the acquisition of a 3D image, the ultrasound transducer was removed from the surgical site.

The acquisition of a 3D image was possible: in two reciprocally perpendicular planes; in the sagittal, coronal and axial planes; and in each of the above-mentioned planes.

Further, an ultrasound probe, calibrated by a reference star or other instrument that can be calibrated, was used. During the navigation procedure, the maintenance of a 15-second expiratory state of the patient is of utmost importance.

\section{RESULTS}

Altogether 28 patients with intradural location of spinal tumours were operated on, consisting of 6 patients with intramedullary tumours and 22 patients with extra-medullary tumours (Table I).

In the group of the intra-medullary tumours, complete excision was achieved for 4 intra-medullary ependymomas, sub-total excision for 1 conus medullaris ependymoma and partial excision for 1 intra-medullary astrocytoma. The average score of the patients with intra-medullary tumours on the Karnofsky Performance Scale at the third post-operative month was 72 points.

In 21 cases with extra-medullary tumours, total excision of the tumour was achieved. In 1 case of filum terminale ependymoma a sub-total excision was performed. The average score of the patients with extra-medullary tumours on Karnofsky Performance Scale at the third post-operative month was $93(+/-7)$ points.

Intraoperatively, the SonoWand ultrasound-based neuronavigation system was used in all 28 cases. The patients were operated in the prone position. The tumour was situated in the cervical spine in 8 , in the thoracic spine in 16 , and in the lumbar spine in the remaining 4 patients. In all cases, after the realization of laminectomy or hemi-laminectomy, B-scan sonographies were performed on the dura, orientative for the exact tumour location and motility of the structures in the spinal canal. In 8 of the cases, intraoperative 3D neurosonographies were performed, while in the rest 20 cases, neuronavigation procedures were successfully carried out. The registration mean time during a 3D ultrasonography was $8 \pm 3$ seconds. The registration mean time during a navigation procedure was $14 \pm 4$ seconds. The mean time of the neuronavigation procedure was $17 \pm 3$ seconds, as within this period, the patient was maintained in a state of expiration. In comparison with the non-navigated surgical procedures, the overall operative time was prolonged no more than 5 to 10 minutes due to the application of ultrasound-based neuronavigation.

Based on histological examination, the cases were distributed, as follows: intramedullary ependymoma $(n=5)$, intramedullary astrocytoma $(n=1)$, filum terminale ependymoma $(n=4)$, neurinoma $(n=8)$ and meningioma $(n=10)$. Based on the orientative 2D (B-scan) sonographies, performed in all patients, the echogenicity and differentiation of the tumour from the adjacent structures, as well as the presence of microor macrocysts within the tumour, were evaluated (Table I). 
Table I: The Results of the Performed Intraoperative Neurosonographic Interventions

\begin{tabular}{|c|c|c|c|c|c|c|c|c|c|}
\hline & \multirow{2}{*}{ Localization } & \multirow{2}{*}{ Histology } & \multirow{2}{*}{$\begin{array}{l}\text { Micro- } \\
\text { cyst }\end{array}$} & \multirow{2}{*}{$\begin{array}{c}\text { Macro- } \\
\text { cyst }\end{array}$} & \multicolumn{2}{|c|}{ Echogenecity } & \multirow{2}{*}{ Mobility } & \multirow{2}{*}{$\begin{array}{c}\text { 3-D } \\
\text { echography }\end{array}$} & \multirow{2}{*}{$\begin{array}{l}\text { Navi- } \\
\text { gation }\end{array}$} \\
\hline & & & & & Iso- & Hyper- & & & \\
\hline \multirow{4}{*}{$\begin{array}{l}\text { Intra- } \\
\text { medullary } \\
\text { tumours } \\
(n=6)\end{array}$} & \multirow{3}{*}{$\begin{array}{l}\text { Spinal } \\
\text { cord }\end{array}$} & $\begin{array}{l}\text { Astrocytoma II gr. } \\
(n=1)\end{array}$ & - & - & + & - & + & $\begin{array}{c}+ \\
\text { artifacts }\end{array}$ & - \\
\hline & & $\begin{array}{l}\text { Ependymoma II gr. } \\
(\mathrm{n}=3)\end{array}$ & + & - & + & - & + & $\begin{array}{c}+ \\
\text { artifacts }\end{array}$ & - \\
\hline & & $\begin{array}{l}\text { Mixopapillary } \\
\text { ependymoma I gr. } \\
(n=1)\end{array}$ & - & + & + & - & + & $\begin{array}{c}+ \\
\text { artifacts }\end{array}$ & - \\
\hline & $\begin{array}{l}\text { Conus } \\
\text { medullaris }\end{array}$ & $\begin{array}{l}\text { Mixopapillary } \\
\text { ependymoma I gr. } \\
(n=1)\end{array}$ & + & - & - & + & ++ & $\begin{array}{c}+ \\
\text { artifacts }\end{array}$ & - \\
\hline \multirow{5}{*}{$\begin{array}{l}\text { Extra- } \\
\text { medullary } \\
\text { tumours } \\
(n=22)\end{array}$} & \multirow{3}{*}{$\begin{array}{l}\text { Cervical } \\
\text { and } \\
\text { Thoracic } \\
\text { regions } \\
\text { (C1-Th12) }\end{array}$} & $\begin{array}{l}\text { Meningioma } \\
(n=10)\end{array}$ & - & - & - & ++ & - & + & + \\
\hline & & $\begin{array}{l}\text { Neurinoma } \\
\text { Anthony A } \\
(n=3)\end{array}$ & - & - & - & + & - & + & + \\
\hline & & $\begin{array}{l}\text { Neurinoma } \\
\text { Anthony B } \\
(n=5)\end{array}$ & + & + & - & + & - & + & + \\
\hline & \multirow{2}{*}{$\begin{array}{l}\text { Lumbar } \\
\text { region } \\
\text { (L1-L5) }\end{array}$} & $\begin{array}{l}\text { Ependymoma II } \\
\text { gr. }>3 \mathrm{~cm}^{3} . \\
(n=3)\end{array}$ & + & - & - & + & - & + & + \\
\hline & & $\begin{array}{l}\text { Mixopapillary } \\
\text { ependymoma I gr. } \\
<3 \mathrm{CM}^{3} \text {. } \\
(\mathrm{n}=1)\end{array}$ & - & - & - & + & + & $\begin{array}{c}+ \\
\text { artifacts }\end{array}$ & - \\
\hline
\end{tabular}

The intratumour cysts with a diameter more than $5 \mathrm{~mm}$ were determined as macrocysts and were observed in 3 of the cases ( 1 intramedullary ependymoma and 2 extramedullary neurinomas), while the intratumour cysts with a diameter less than $5 \mathrm{~mm}$ were defined as microcysts and were observed in 6 of the cases ( 1 intramedullary ependymoma, 1 conus medullaris ependymoma, 2 filum terminale ependymomas and 2 extramedullary neurinomas).

The examined intramedullary tumours were isoechoic, compared to the myelon, with the exception of conus medullaris ependymoma. The surgeon's orientation and intraoperative ultrasound-based determination of the extent of radical excision were impeded by the isoechogenicity of this type of tumours. The ependymoma in the region of conus medullaris was well demarcated, but the myelon motility in this area was a prerequisite for the occurrence of artifacts, due to normal physiological movements. For the series of examined intramedullary tumours, 3D images were successfully acquired; however, no navigation procedure was performed. Only the realized visualization of macrocysts was beneficial for initiating the tumour microdissection.
The number of examined filum terminale ependymomas was 4 , and the volume of 3 of them were more than $3 \mathrm{~cm}^{3}$, thus occupying the entire intradural space. They were relatively immobile, and a navigation procedure prior to the incision of the dura was therefore successfully performed. Compared to the adjacent tissues, these tumours were generally hyperechoic and well demarcated, thus facilitating the exact determination of their borders. After the performance of internal decompression of the tumour, however, the residual portion of the tumour was more motile and the realization of a navigation procedure was impossible.

As a tumour originating from the nerve root, the neurinoma remains firmly attached to it; on the other hand, after reaching certain dimensions, it compresses the spinal cord, dislocates the arachnoid membranes and adheres between the spinal cord and the dura. Generally, neurinomas are hyperechoic, compared to the adjacent structures, with presented microand macrocysts. Hence, the performance of a navigation procedure, preceding and following the disclosure of the dura, was successfully carried out in all operated neurinomas (Figure 2A,B). 
All examined meningiomas were hyperechoic and well demarcated, compared to the adjacent structures in the spinal canal. In some meningiomas, hyperechoic zones were observed, probably due to the presence of calcification within the tumour. They were immobile and attached with a large base towards the dura, thus enabling the performance of a navigation procedure (Figure $3 A, B$ ).

\section{DISCUSSION}

Three-dimensional neurosonography was used for the first time in 1995, in obstetrics (19). The technique was successfully applied by Johnson et al. in 1997, for spatial visualization of the structures in the fetal spinal canal (13). In 2000, the concept of combining the 3D ultrasound and neuronavigation was technologically developed by the SonoWand ultrasoundbased navigation system (12).

The ultrasound-based neuronavigation device is a very expensive tool, but if it is available in the operating theatre its application in spinal cord tumour surgery in every particular case is not associated with any additional costs.

The operative and functional results with the application of this type of technology are not much different from the cases in which only microsurgical techniques were applied.
The main advantage of this type of technology is the possibility for a real-time 3D representation of the structures in the spinal canal. Thus, the surgeon is assisted in getting the correct idea of the spatial interrelations of these structures, preceding their visualization, as well as in locating precisely the position and size of durotomy and myelotomy. The initiation of tumour microdissection is facilitated by the clear visualization of microcysts presented in the intramedullary tumour. The possibility of fast, repeated registration of the targets within the surgical site is beneficial in the conditions of dynamically changing surgical situation. Based on a 3D ultrasound reconstruction of the image, the navigation procedure is performed in one coordinate system, thus enabling direct 3D image reconstruction and avoiding the necessity of pre-registered anatomical landmarks. In this way, the error, originating from the transformation of coordinate systems is avoided, thus making the method more precise. The accuracy of the SonoWand ultrasound navigation system, tested under laboratory conditions, is about $1.7 \mathrm{~mm}$ (14). It is similar to that of the CT and MRI-based neuronavigational devices $(3-10,18,23)$. A source of error could be the generated technological image distortion, compared with the real target (2).

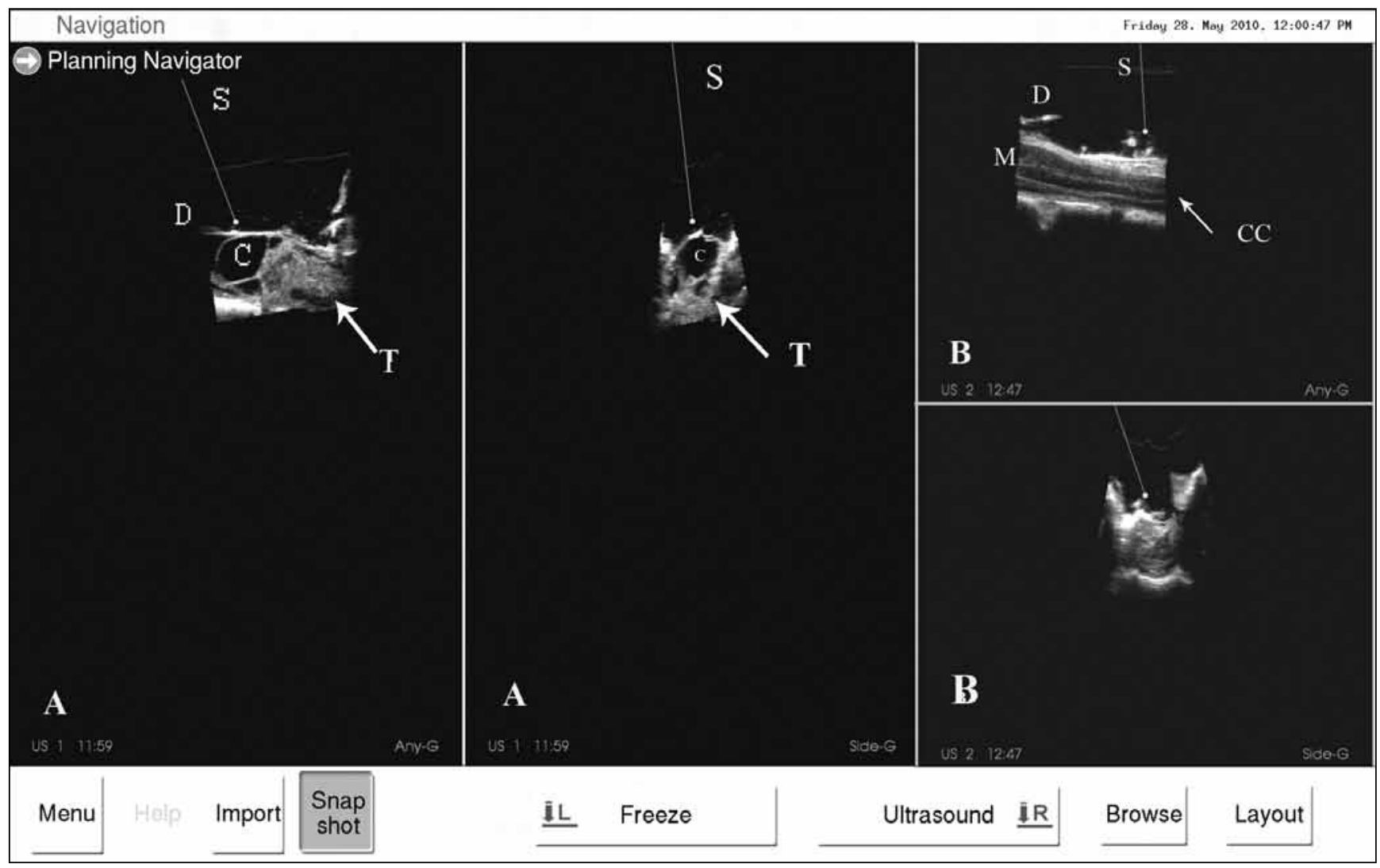

Figure 2: Neuronavigated spinal surgery in neurinoma containing microcyst (Antony B histological type). The neuronavigated procedure is performed before opening the dura mater (A) and after tumour removal (B) as the images are in 2 perpendicular planes. The procedure was conducted using neuronavigation station SonoWand Invite ${ }^{\mathrm{TM}}$ and a $12 \mathrm{Mhz}$ transducer. Abbreviations: C-cyst; CCcanalis centralis; $\mathbf{D}$-dura mater; $\boldsymbol{T}$-tumour; $\mathbf{S}$-probe sonde. 


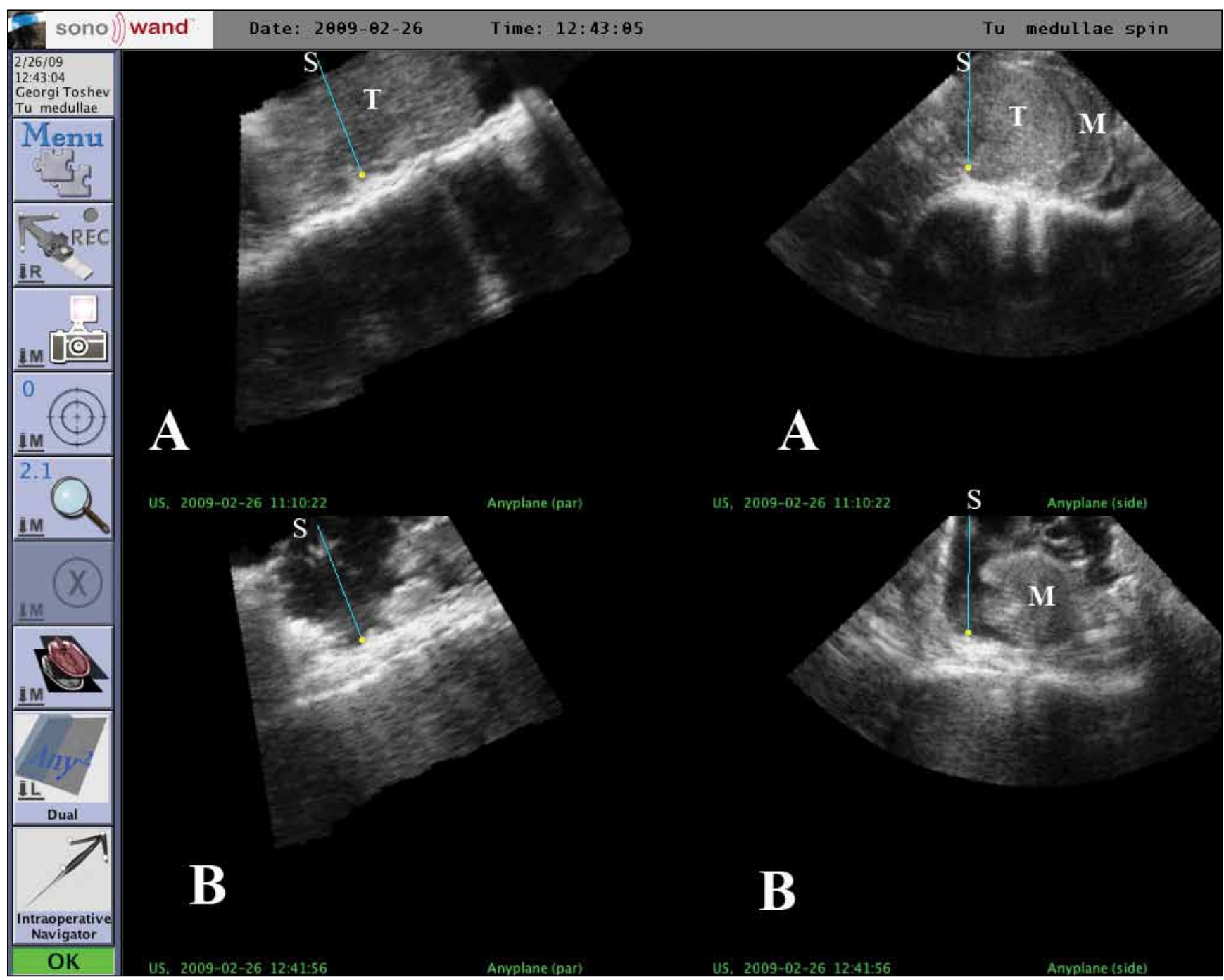

Figure 3: Neuronavigated resection of meningioma located in the cervical spine, ventral to spinal cord, causing a sickle-shaped deformation of the latter. Neuronavigation is applied before opening the dura mater (A) and after tumour removal (B). The gross total resection was verified using the neuronavigation system by following the probe position in the tumour bed and comparing the images to the preoperative ones. The procedure was conducted using the neuronavigation station SonoWand and a $10 \mathrm{Mhz}$ transducer. Abbreviations: M-myelon; S-probe sond; T-tumour.

The way of fixation of the reference star could be also a source of error. In surgical interventions for syringomyelia, some authors have attached the reference star to the operating table (1). Others have recommended the fixation of the reference star to the spinous process of the adjacent vertebra, to avoid the artifacts resulting from the respiratory movements (14). In our study, the reference star was attached to the operating table and the patient was maintained in a state of expiration during the registration and navigation processes. In our opinion, the changes in thoracic pressure, realized via the communicative veins between the systems of azygos vein and the epidural venous plexus, have their influence on cerebrospinal fluid (CSF) pressure. The change in CSF pressure is a prerequisite for the occurrence of a pressure gradient around the tumour and for the motility of the structures in the spinal canal. Therefore, we tried to avoid the additional artifacts associated with the respiratory movements. There are also reported pulsations of the spinal cord, synchronous with the cardiac cycle. These pulsations may result in spinal cord motility, most pronounced in the cervical spinal segment and in the region of conus medullaris. These movements are cranio-caudally directed and are within the range of 0.5 to $1 \mathrm{~mm}$ (15).

The application of ultrasound-based neuronavigation in intramedullary tumour surgery is also limited by the isoechogenicity of most intramedullary tumours. In all our cases of spinal cord tumour removal, a hyperechoic line was observed in the bed of the extirpated tumour. This line was present even after thorough hemostasis and repeated lavage of the surgical site with sterile saline solution. 
The advancement in ultrasound imaging technologies in practice has introduced transducers with a working frequency of 15 and $18 \mathrm{MHz}$, which makes it possible to receive images of structures in the spinal canal with precision. Unfortunately, so far no ultrasound-based navigation systems work with such transducers. The question about the application of intraoperative power Doppler images of the vascular structures located in the spinal canal has not yet been studied (25). Although the scarce literature concerning this problem, and the ongoing discussion on the application of ultrasoundbased neuronavigation in spinal cord tumour surgery, we consider that in near future such technologies will elevate its value in spinal surgery at all.

\section{CONCLUSION}

Based on our results we can conclude that the application of ultrasound-based neuronavigation in spinal cord tumour surgery requires two important conditions. First, good ultrasound visibility of the objects in the operative field, allowing clear delineation of the tumour from the surrounding structures. Second, relative immobility of the objects located in the coordinate system defined by the reference star. Currently, these conditions are feasible only in the group of the extramedullary tumours. In intramedullary tumours the implementation of 3D sonography would be possible just after elimination of motion artifacts due to respiration. In general, ultrasound-based neuronavigation has not added much to the surgical management of spinal cord tumors.

\section{REFERENCES}

1. Bonsanto MM, Metzner R, Aschoff A, Tronnier V, Kunze S, Wirtz CR: 3D ultrasound navigation in syrinx surgery-a feasibility study: Acta Neurochir (Wien) 147:533-541, 2005

2. Dean D, Kamath J, Duerk JL, Ganz E: Validation of object induced MR distortion correction for frameless stereotactic neurosurgery. IEEE Trans Med Imaging 17:810-816, 1998

3. Enchev Y, Bozinov O, Miller D, Tirakotai W, Heinze S, Benes L, Bertalanffy $\mathrm{H}$, Sure U: Image-guided ultrasonography for recurrent cystic gliomas. Acta Neurochir (Wien) 148(10): 1053-1063, 2006

4. Enchev Y, Oi S: Historical trends of neuroendoscopic surgical techniques in the treatment of hydrocephalus. Neurosurg Rev 31(3):249-262, 2008

5. Enchev YP, Popov RV, Romansky KV, Marinov MB, Bussarsky VA: Role of neuronavigation in the resection of intracranial arteriovenous malformations. Folia Med (Plovdiv) 50(1): 40-45, 2008

6. Enchev YP, Popov RV, Romansky KV, Marinov MB, Bussarsky VA: Cranial neuronavigation-a step forward or a step aside in modern neurosurgery. Folia Med (Plovdiv) 50(2):5-10, 2008

7. Enchev YP, Popov RV, Romansky KV, Marinov MB, Bussarsky VA: Neuronavigated surgery of intracranial cavernomas-enthusiasm for high technologies or a gold standard? Folia Med (Plovdiv) 50(2):11-17, 2008
8. Enchev YP, Popov RV, Romansky KV, Marinov MB, Bussarsky VA: Effect of the type of image study (CT or MRI) on some parameters of neuronavigation-assisted procedures. Folia Med (Plovdiv) 50(3):47-52, 2008

9. Enchev Y: Neuronavigation: Geneology, reality and prospects. Neurosurg Focus 27(3): E11, 2009

10. Enchev Y, Tzekov C, Ferdinandov D, Cekov A, Spiriev T: Neuronavigation in cranioorbital neurosurgery - do we really need it? Turk Neurosurg 21(2):119-126, 2011

11. Foley KT, Smith MM: Image-guided spine surgery. Neurosurg Clin N Am 7:171-186, 1996

12. Gronningsaeter $A$, Kleven $A$, Ommedal $S$, Aarseth $T E$, Lie T, Lindseth F, Lango T, Unsgard G: SonoWand, an ultrasoundbased neuronavigation system. Neurosurgery 47:1373-1379, 2000

13. Johnson DD, Pretorius DH, Riccabona M, Budorick NE, Nelson TR: Three-dimensional ultrasound of the fetal spine. Obstet Gynecol 89:434-438, 1997

14. Kolstad F, Rygh OM, Selbekk T, Unsgaard G, Nygaard OP: Three-dimensional ultrasonography navigation in spinal cord tumor surgery. Technical note. J Neurosurg Spine 5: 264-270, 2006

15. Mikulis DJ, Wood ML, Zerdoner OA, Poncelet BP Oscillatory motion of the normal cervical spinal cord. Radiology 192: 117-121, 1994

16. Mimatsu K, Kawakami N, Kato F, Saito H, Sato K: Intraoperative ultrasonography of extramedullary spinal tumours. Neuroradiology 34:440-443, 1999

17. Nolte LP, Visarius $H$, Arm E, Langlotz F, Schwarzenbach $O$, Zamorano L: Computer-aided fixation of spinal implants. J Image Guid Surg 1:88-93, 1995

18. Oi S, Enchev Y: Neuroendoscopic foraminal plasty of foramen of Monro. Childs Nerv Syst 24(8):933-942, 2008

19. Pretorius $\mathrm{DH}$, Nelson TR: Fetal face visualization using threedimensional ultrasonography. J Ultrasound Med 14:349-356, 1995

20. Regelsberger J, Langer N, Fritzsche $E$, Westphal $M$ : Intraoperative ultrasound of intra- and extramedullary tumours. Ultraschall Med 24:399-403, 2003

21. Reid MH: Ultrasonic visualization of a cervical cord cystic astrocytoma. AJR Am J Roentgenol 131:907-908, 1978

22. Sciubba DM, Liang D, Kothbauer KF, Noggle JC, Jallo GI: The evolution of intramedullary spinal cord tumor surgery. Neurosurgery 65:84-91, 2009

23. Shamov T, Spiriev T, Tzvetanov P, Petkov A: The combination of neuronavigation with transcranial magnetic stimulation for treatment of opercular gliomas of the dominant brain hemisphere. Clin Neurol Neurosurg 112(8):672-677, 2010

24. Shamov TP, Eftimov TN: Ultrasound neuronavigation in spinal cord surgery. Military medicine (Sofia) 4:13-18, 2010

25. Unsgaard G: Ultrasound-guided neurosurgery. In: Sindow M, (ed), Practical Handbook of Neurosurgery from Leading Neurosurgeons. Vienna: Springer, 2009:407-427 